ZOOLOGIA 29 (4): 380-384, August, 2012

doi: $10.1590 /$ S1984-46702012000400010

\title{
Redescription of Misumenoides athleticus comb. nov. (Araneae: Thomisidae), wrongly assigned to the philodromid genus Petrichus
}

\author{
Renato Augusto Teixeira' \& Arno Antonio Lise ${ }^{2}$
}

\author{
${ }^{1}$ Laboratório de Entomologia, Universidade Federal do Rio Grande do Sul. Porto Alegre, RS, Brazil. \\ E-mail: renatoaug.tx@gmail.com \\ ${ }^{2}$ Laboratório de Aracnologia, Museu de Ciências e Tecnologia, Pontifícia Universidade Católica do Rio Grande do Sul. \\ Avenida Ipiranga 6681, Caixa Postal 1429, 90619-900 Porto Alegre, RS, Brazil.
}

\begin{abstract}
Petrichus athleticus Mello-Leitão, 1944 was described from Punta Piedras, Argentina, based on male and female specimens. The species was originally wrongly assigned to Petrichus Simon, 1886 because it has the cephalic region more elevated than the carapace region. However, examination of the holotype has revealed the presence of lateral eye tubercles, and legs I and II longer and stouter than legs III and IV. These characteristics are considered synapomorphic for the Thomisidae. Furthermore, the presence of an epigynal hood (type "hood pocket"), RTA long with simple base and modified apex, absence of tutaculum, and short setae on the surface of the carapace and abdomen corroborate that P. athleticus belongs to Misumenoides F.O.P.-Cambridge, 1900. In this paper, we assign P. athleticus to Misumenoides, redescribe the species, illustrate it for the first time, and extend its known distribution.
\end{abstract}

KEY WORDS. Argentina; crab spider; taxonomy.

Petrichus Simon, 1886 was originally placed in Thomisidae, in Philodrominae (SIMON 1886). It was considered an "intermediate group" between the Philodrominae and the Thomisinae until the Philodrominae was given family status (Homann 1975).

Petrichus athleticus Mello-Leitão, 1944 was described from Punta Piedras, Argentina, based on male and female specimens. Mello-Leitão (1944) characterized it by the following characters: cephalic region more elevated than the carapace region; anterior row of eyes strongly recurved, posterior row of eyes little recurved; legs II and IV sub equal, leg formula 2-4-1-3 with poorly developed scopula and claw tufts. The examination of the type of $P$. athleticus revealed the presence of tubercles on the lateral eyes, and legs I and II longer and stouter than legs III and IV, characteristics considered synapomorphic for the Thomisidae (Benjamin 2011).

The assignment of $P$. athleticus in Misumenini sensu LEHTINEN (2005) is based on the presence of an epigynal hood and the absence of modifications on the carapace and abdomen (e.g., lateral eye tubercles not shaped as a horn, and carapace and abdomen lacking tubercles).

The allocation of P. athleticus in Misumenoides F.O.P.-Cambridge, 1900 is proposed after comparing the characteristics of the species with the diagnostic traits of the Neotropical genera currently classified in Minimenini sensu Lehtinen (2005). We decided that $P$. athleticus does not belong in any of the genera listed below for the following reasons: 1) Erissoides Mello-Leitão,
1929. In P. athleticus, the tarsi, the metatarsi and the tibial apex are not dark, and the epyginal hood does not form a wide arc; 2) Misumena Latreille, 1804. In our species, the apex of the embolus is not screwed, nor the epyginal hood is narrow; 3 ) Misumenops F.O.P.-Cambridge, 1900. In P. athleticus, a small tutaculum is not found; 4) Runcinioides Mello-Leitão, 1929. Our species does not have long and strong setae on the carapace and abdomen, and the tutaculum and tutacular groove along tegular margin (LeHTINen \& MARUSIK 2008); and 5) Urarachne Keyserling, 1880 . The abdomen of $P$. athleticus is not elongated.

Petrichus athleticus has a long RTA with simple base and modified apex in ITA, and RTA fused, as in the diagnosis of Misumenoides (Lehtinen 2005). At first analysis, the assignment of $P$. athleticus to Misumenoides may be incongruent because of the presence of a transversal carina on the ocular area of the former. According to Lehtinen (2005), species of Misumenoides have a chalk-white transversal carina on the ocular area. However, the study of some species of Misumenoides showed that there may be a transversal white stripe on the ocular area that lack such carina (e.g., Misumenoides eximius Mello-Leitão, 1938, M. carminatus Mello-Leitão, 1941, M. variegatus Mello-Leitão, 1941, M. gerchmani Mello-Leitão, 1944 e M. proseni Mello-Leitão, 1944). For this reason, we assign Petrichus athleticus to Misumenoides. We also redescribe the species, illustrate it for the first time, and provide records that extend its known distribution. 


\section{MATERIAL AND METHODS}

Type-specimens are deposited in the collection of the Museo de La Plata (MLP, L.A. Pereira), and other specimens are available at the collection of Museu de Ciências Naturais da Fundação Zoobotânica do Rio Grande do Sul (MCN, E.H. Buckup). The description format and morphological terminology were adapted from Bonaldo \& Lise (2001), Lehtinen (2005) and LISE (2005). Annotations about the male copulatory organ are made from the left palp and use the clock hours to express the disposition of some structures, as in Lehtinen \& Marusik (2008). The measurements are in millimeters and the used abbreviations for eyes and legs are standard in Arachnology. Specimens were illustrated with Adobe ${ }^{\circledR}$ Illustrator CS5 and Photoshop CS5.

\section{TAXONOMY}

\section{Misumenoides athleticus (Mello-Leitão, 1944) comb. nov.}

Figs 1-12

Petrichus athleticus Mello-Leitão, 1944: 369 (Lectotype female and paralectotype male from Punta Piedras, Buenos Aires: Argentina, deposited at MLP 16180, examined). Pereira et al., 1999: 81; Platnick, 2012.

Diagnosis. Misumenoides athletichus comb. nov. differs from all species of Misumenoides by having the setae with rounded apices(Fig. 2), male tibiae I and II slightly enlarged, with a setae thickening on the ventral surface (Fig. 8), the ITA short with rounded apex and RTA long and thin, almost reaching the tegulum apex (Figs 9-11). The shape of the epigynum is similar to that of Misumenoides corticatus Mello-Leitão, 1929, but differs by having the hood pocket longer (Figs 3-5).

Description. Female (MLP 16180). Prosoma brown with a broad yellow longitudinal band and a narrow dark longitudinal stripe on posterior portion. Lateral margins of carapace bordered with yellow. Tegument without macrosetae, covered by spatulate setae and bearing a row of setae on lateral margins (Fig. 1). Vertical clypeus with nine setae, one median and the other forming four equidistant marginal pairs. Chelicera, labium and endites, yellow. Sternum light yellow with a brown arrow-like spot on posterior half. Legs light yellow with brown spots on apex of femora, and patellae I-IV and tibiae and metatarsi III and IV. Patellae, tibiae, metatarsi, tarsi I and II, dark yellow. Abdomen light yellow with dark spots around the dorsal sigillae, and along longitudinal median band on venter. Abdomen laterally furrowed, and tegument covered by spatulate setae. Total length 3.88. Prosoma: 1.92 long, 1.95 wide. Clypeus height 0.14 . Chelicerae: 0.60 long, 046 wide. Sternum: 0.92 long, 0.84 wide. Endites: 0.58 long, 0.22 wide. Labium: 0.38 long, 0.32 wide. Eye diameters and interdistances: AME 0.06, ALE 0.08, PME 0.07, PLE 0.06, AME-AME 0.24, AME-
ALE 0.16, PME-PME 0.25, PME-PLE 0.17. MOQ sub-square, wider than longer, length in dorsal view 0.25 , anterior width 0.36 , posterior width 0.39 . Anterior and posterior eye rows recurved, anterior one less recurved. Leg spination: femur I p1-0-0/femura II-IV d0-1-0/tibia I v0-1(p)-2-2-2/tibia II v0-02-2/tibiae III-IV d0-1-0/metatarsus I v2-2-2-2-2(ap)/metatarsus II v2-2-1(r)-2-2(ap). Relative length of legs: 1243. Measurements: I - femur 1.88 /patella $0.84 /$ tibia $1.40 /$ metatarsus 1.22 tarsus $0.78 /$ total 6.12 ; II $-1.78 / 0.74 / 1.02 / 0.62$ / 5.40; III - 1.02/0.50/0.68/0.58/0.42/3.20; IV - 1.18/0.50/0.82/ 0.64/0.52/3.66. Abdomen: 2.20 long, 2.33 wide. Epigynum: epigynal plate with a sinuous shallow triangular depression. Atrium shallow on posterior portion of epigynal plate, and deep on anterior portion, near hood pocket. Epigynal fold anteriorly concave, with a long hood pocket. Hood pocket visible by transparency through the epigynal plate, longer than the distance between its opening and the copulatory openings. Copulatory ducts sinuous and positioned above the rounded spermathecae (Fig. 5).

Male (MLP 16180). Prosoma coloration as described for the female, but with yellow longitudinal stripe narrower and darker (Fig. 6). Chelicera pale brown. Clypeus, endites, labium and sternum as in female. Legs I and II dark yellow, except by reddish-brown tibia. Tibiae I and II robust with many setae, mainly on ventral surface (Fig. 8). Legs III and IV yellow, spotted with black on apex of segments, except tarsus. Abdomen coloration as in female, but with dorsal dark spots on more dense. Total length 2.08. Prosoma: 0.98 long, 1.16 wide. Clypeus height 0.09 . Chelicera 0.29 long, 0.20 wide. Sternum 0.54 , long, 0.54 wide. Endites 0.28 , long, 0.14 wide. Labium 0.23 long, 0.15 wide. Eyes diameters and interdistances: AME 0.05, ALE 0.07, PME 0.05, PLE 0.05, AME-AME 0.12, AME-ALE 0.09, PMEPME 0.13, PME-PLE 0.14. MOQ sub-square, wider than long, length in dorsal view 0.16 , anterior width 0.22 , posterior width 0.25 . Eye rows as in female. Leg spination: femur I-IV d0-1-0/ femur I p1-1-0-0/tibia I v0-0-2-1(r)/tíbia II 0-0-2-2/tibia III d01-0/tibia IV d1-1-0/metatarsus I-II v2-2-2-2(ap). Relative length of legs: 1243 . Measurements: I - femur 1.42/patella 0.52/tibia 1.10 /metatarsus $1.03 /$ tarsus $0.69 /$ total 4.76 ; II - 1.30/0.45/1.00/ $0.87 / 0.65 / 4.27$; III - 0.62/0.26/0.42/0.36/0.36/2.02; IV - 0.62/ $0.28 / 0.45 / 0.36 / 0.37 / 2.08$. Abdomen 1.10 long, 1.15 wide. Palpus: ventral tibial apophysis triangular and short. RTA medially joins with ITA. ITA short with rounded apex and RTA long and thin (Figs 9-11), almost reaching the tegulum apex. Tegulum, longer than wide with a prolateral depression near the origin of tegular ridge. Embolus originates at eight hours and circumvents nearly $180^{\circ}$ of the tegulum.

Material examined. BraziL, Rio Grande do Sul: Dom Pedrito (Rincão dos Barretos, 3058'S, 54 40’ W), 1 female, 23-29.I.2011, R. Moraes et al. leg. (MCN 48910); Bagé (Estância Leões, $31^{\circ} 06^{\prime}$ 'S, $\left.54^{\circ} 06^{\prime} \mathrm{W}\right), 1$ male and 1 female, 426.X-02.XI.2010, R. Moraes et al. leg. (MCN 48902 and 48911 respectively).

Distribution. Southern Brazil to Eastern Argentina (Fig. 12). 

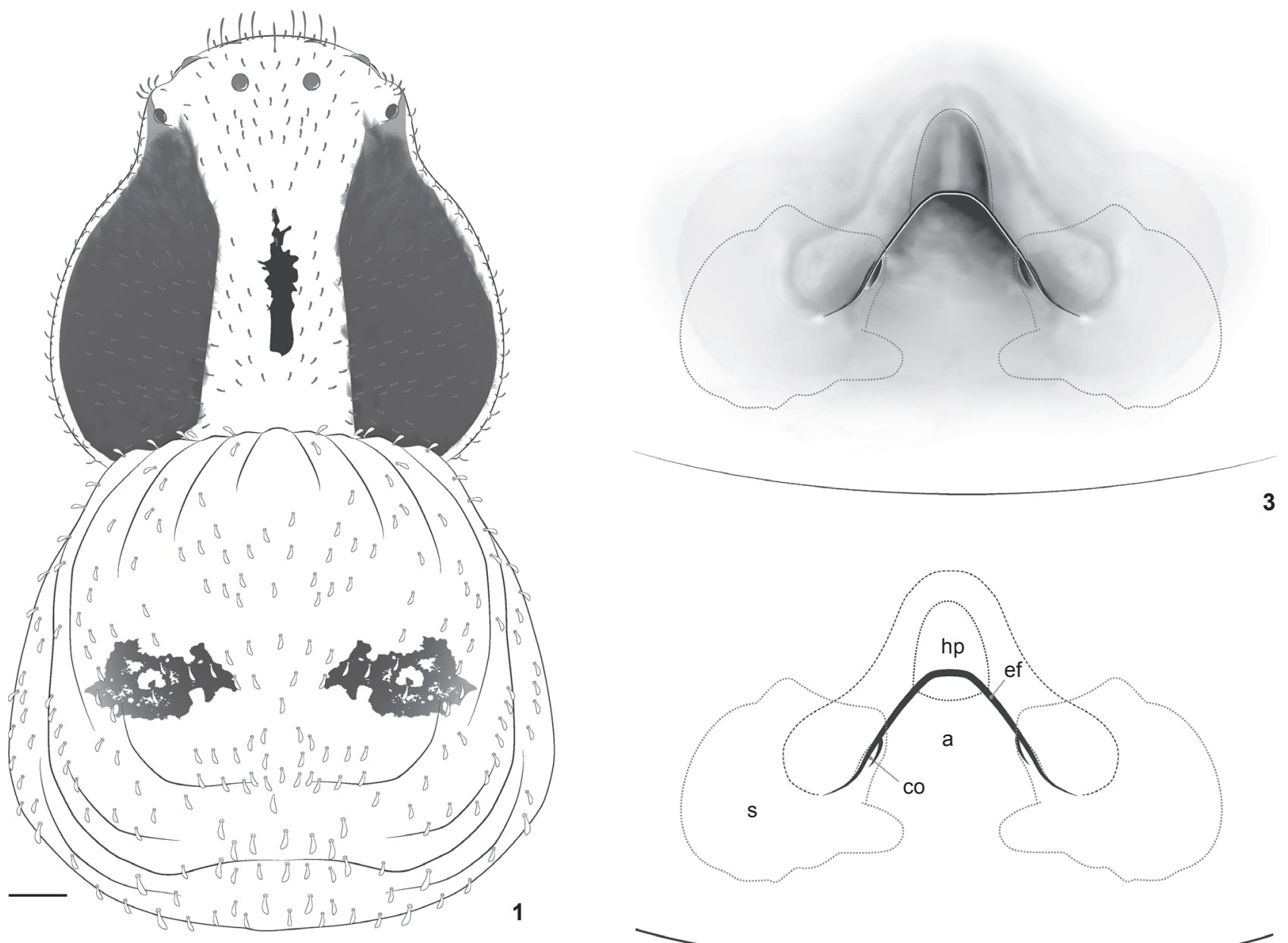

4
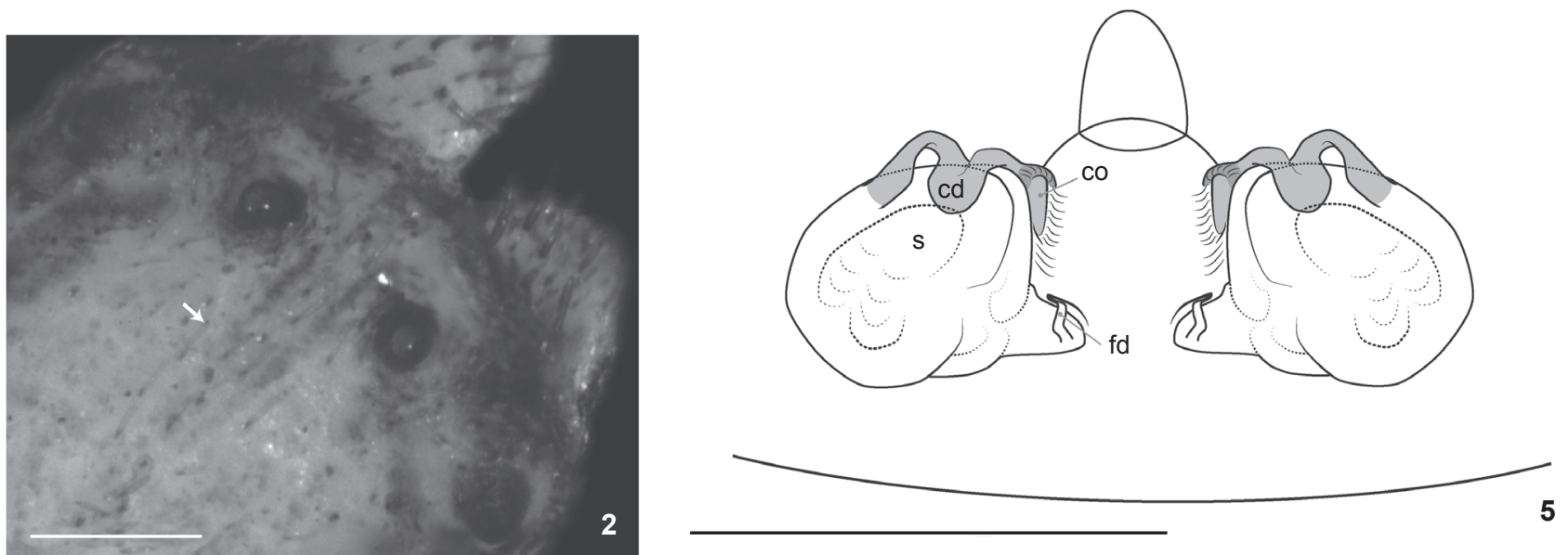

Figures 1-5. Misumenoides athleticus comb. nov., female: (1) habitus, dorsal view; (2) detail of carapace showing spatulate setae, white arrow; (3) epigynum, ventral view; (4) outline of the epigynum, ventral view; (5) epigynum, dorsal view. Scale bar: $0.25 \mathrm{~mm}$. (a) Atrium, (cd) copulatory duct, (co) copulatory opening, (ef) epigynal fold, (fd) fertilization duct, (hp) hood pocket, (s) spermathecae. 

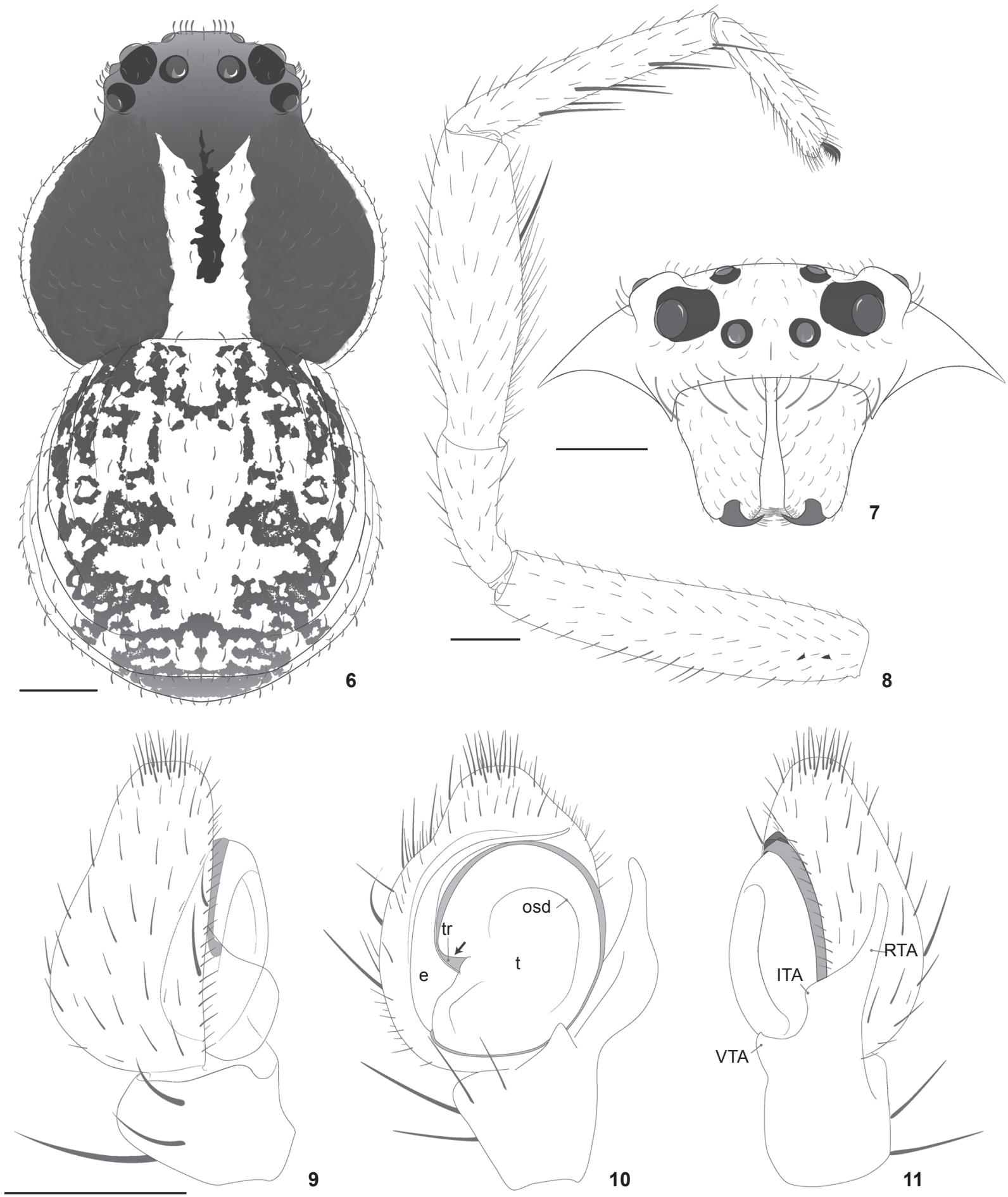

Figures 6-11. Misumenoides athleticus comb. nov., male: (6) habitus, dorsal view; (7) carapace, frontal view; (8) left leg I, proloateral view; (9-11) male palp: (9) prolateral; (10) ventral; (11) retrolateral view. Scale bar: $0.25 \mathrm{~mm}$. (e) Embolus, (ITA) intermediate tibial apophysis, (osd) outline of the sperm duct, (RTA) retrolateral tibial apophysis, (VTA) ventral tibial apophysis, (t) tegulum, (tr) tegular ridge. Black arrow indicates depression near the origin of tegular ridge. 


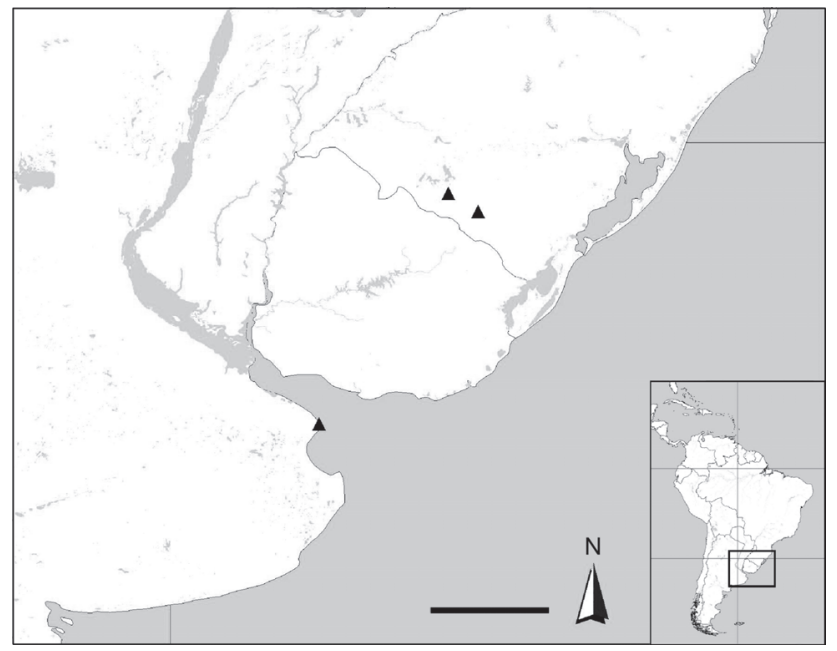

Figure 12. Distribution of Misumenoides athleticus comb. nov. in southern of South America. Scale bar: $250 \mathrm{~km}$.

\section{ACKNOWLEDGEMENTS}

We are grateful to L.A. Pereira and E.H. Buckup by specimen's loan. Thanks are also extended to R. Ott, who provided a female for dissection; A. Ferrari who, helped with some images, and K.R. Barão and three anonymous referees for helpful suggestions on the manuscript. This study was supported by CNPq (Conselho Nacional de Desenvolvimento Científico e Tecnológico, process 141425/2010-5) and is part of the doctor dissertation of the first author at the Instituto de Biociências of the Universidade Federal do Rio Grande do Sul.

\section{LITERATURE CITED}

Benjamin, S.P. 2011. Phylogenetics and comparative morphology of crab spiders (Araneae: Dionycha, Thomisidae). Zootaxa 3080: 1-108.

Bonaldo, A.B. \& A.A. Lise. 2001. A review of the Neotropical spider genus Stephanopoides (Araneae, Thomisidae, Stephanopinae). Biociências 9: 63-80.

Cambridge, F.O.P. 1900. Arachnida - Araneida and Opiliones, p. 89-192. In: Biologia Centrali-Americana, Zoology. London, Taylor \& Francis.

Submitted: 24.X.2011; Accepted: 05.VI.2012.

Editorial responsibility: Antonio D. Brescovit
Homann, H. 1975. Die Stellung der Thomisidae und der Philodromidae im System der Araneae (Chelicerata, Arachnida). Zeitschnft fur Morphologic der Tiere 80: 181-202.

Keyserling, E. 1880. Die Spinnen Amerikas, I. Laterigradae. Nürnberg 1: 1-283.

Latreille, P. A. 1804. Histoire naturelle générale et particulière des Crustacés et des Insectes. Paris, vol. 7, p. 144-305.

Lehtinen, P.T. 2005. Taxonomic notes on the Misumenini (Araneae: Thomisidae: Thomisinae), primarily from the Palaearctic and Oriental regions. In: D.V. Logunov \& D. Penney (Eds). European Arachnology 2003 [Proceedings of the 21st European Colloquium of Arachnology, St.-Petersburg, 4-9 August 2003]. Arthropoda Selecta, Special Issue 1: 147-184.

Lehtinen, P.T. \& Y.M. MARusik. 2008. A redefinition of Misumenops F.O. Pickard-Cambridge, 1900 (Araneae, Thomisidae) and review of the New World species. Bulletin of the British Arachnological Society 14: 173-198.

LISE, A.A. 2005. Rejanellus, a new genus of Thomisidae (Araneae, Stephanopinae). Iheringia, Série Zoologia, 95: 151-164.

Mello-Leitão, C.F. DE. 1929. Aphantochilidas e Thomisidas do Brasil. Archivos do Museu nacional do Rio de Janeiro 31: 9-359.

Mello-Leitão, C.F. DE. 1938. Algunas arañas nuevas de la Argentina. Revista del Museo de La Plata (N.S., Zool.) 1: 89-118.

Mello-Leitão, C.F. DE. 1941. Las arañas de Córdoba, La Rioja, Catamarca, Tucumán, Salta y Jujuy colectadas por los Profesores Birabén. Revista del Museo de La Plata, N.S. Zoologia, 2: 99-198.

Mello-Leitão, C.F. de. 1941. Las arañas de la provincia de Santa Fe colectadas por el Profesor Birabén. Revista del Museo de La Plata, N.S. Zoologia, 2: 199-225.

Mello-Leitão, C.F. DE. 1944. Arañas de la provincia de Buenos Aires. Revista del Museo de La Plata, N.S., Zoologia, 3: 311393.

Pereira, L.A.; C.A. Sutton \& M.J. Ramírez. 1999. Catálogo de tipos de Araneae (Arachnida) del Museo de La Plata. Neotrópica 45 (113-114): 77-100.

PlatNiCK, N.I. 2012. The world spider catalog, version 12.5. New York, American Museum of Natural History, available online at: http://research.amnh.org/iz/spiders/catalog. [Accessed: 23/V/2012].

Simon, E. 1886. Espèces et genres nouveaux de la famille des Thomisidae. Actes de la Société linnéenne de Bordeaux 40: 167-187. 